\title{
KOMUNIKASI ANTAR PEGAWAI PADA DINAS PEKERJAAN UMUM
}

\author{
Martinus Syamsudin \\ Fakultas Ilmu Sosial dan Ilmu Politik Universitas Kapuas \\ Email: syamsudinmartinus@yahoo.co.id
}

\begin{abstract}
ABSTRAK: Komunikasi pada Dinas Pekerjaan Umum Kabupaten Melawi telah dijalankan dari aspek komunikasi formal digunakankan sebagai media menyampaikan informasi baik dalam kebijakan, uraian tugas pokok dan fungsi serta sebagai pelaporan dan evaluasi dari aspek komunikasi informal adalah sebagai media kebersamakan dalam memberi informasi dan komunikasi. Komunikasi formal Antar Pegawai telah dilakukan dengan berbagai bentuk baik vertikal, harisontal maupun diagonal dan telah difungsikan sebagai sarana penyampaian informasi yang berhubungan kebijak, pembagian tugas, evaluasi dan juga merupakan sebagai fungsi pelaporan dan opini, sedangkan Komunikasi Informal Antar Pegawai pada Dinas Pekerjaan Umum Kabupaten Melawi juga dilakukan walaupun sebatas isu, yang sumbernya belum dapat dipertanggungjawabkan tapi pegawai memilah informasi dalam komunikasi tersebut dan komunikasi informal in juga sebagai media untuk memelihara hubungan sosial persahabatan kelompok informal.
\end{abstract}

Kata Kunci : Komunikasi, Pegawai

Komunikasi akan berhasil apabila pengirim pesan dan penerima pesan sama-sama mencapai pengertian dan kesimpulan yang sama sesuai dengan yang dimaksudkan, tentang apa yang sebenarnya diinformasikan. Untuk itu sangat diperlukan keterampilan dalam pemakaian bentukbentuk komunikasi dari pimpinan sehingga mudah dimengerti, dipahami dan dilaksanakan oleh Pegawai baik yang ada di dalam kantor maupun pegawai yang melayani di lapangan. Pelaksanaan komunikasi yang baik akan berimbas pada jelasnya intruksi, perintah dan arahan pimpinan sehingga pelaksanaan pekerjaan lebih efisien. Kehidupan manusia didunia tidak dapat dilepaskan dari aktivitas komunikasi karena kumunikasi merupakan bagian dari sistem kehidupan sosial menusia dan masyarakat. Aktivitas komunikasi dilakukan sejak manusia ada dan tidak ada manusia hidup tanpa komunikasi dengan orang lain, karena komunikasi yang dilakukan oleh manusia adalah agar apa yang menjadi keinginan dan menjadi pikirannya dapat ditransfer kepada orang lain sehingga terjadi proses penyatuan persamaan persepsi untuk melakukan aktivitas berpikir. Oleh karena itu komunikasi secara umum adalah pemindahan dalam bentuk gagasan atau inforasi dari seseorang kepada orang lain. Pemindahan pengertian tersebut melibatkan lebih dari sekedar kata-kata yang dipergunakan dalam pembicaraan dengan orang lain selama kontak berlangsung.

Komunikasi merupakan proses penyampaian pesan oleh seseorang kepada orang lain, atau oleh komunikator kepada kumunikan. Pesan komunikasi dapat pula diamati dari lambang maupun simbol. Dalam kontek pesan tentang isi pesan dalam komunikasi adalah pikiran, adakalanya juga perasaan, namum semua itu hanya merupakan pengaruh saja. Komunikasi dalam bentuk bahasa lebih mampu memberi makna kepada kehidupan manusia, baik secara konkrit maupun konsep yang abtrak. Pentingnya bahasa sebagai lambang karena bahasa melekat pada pikiran, sehingga tidak mungkin dilepaska dari pikiran. Ini artinya orang berpikir dengan bahasa dan kemampuan berpikir adalah ciri khas munusia sebagai mahluk hidup yang memiliki derajat yang lebih tinggi.

Pelaksanaan Tugas Pokok dan Fungsi pada Dinas Pekerjaan Umum Kabupaten Melawi tentu setiap individu melakukan kontak atau hubungan interaksi antar pegawai satu sama yang lainnya, hal ini berarti perlu adanya kumunikasi yang baik sesama pegawai, namun berdasarkan pengamatan sementara dalam prapenelitian penulis adanya fenomena atau gejala sering terjadinya hambatan dalam komunikasi. Berawal dari pengamatan prapenelitian penulis tersebut maka penulis tertarik untuk melakukan penelitian tentang Komunikasi Antar Pegawai Pada Dinas Pekerjaan Umum Kabupaten Melawi.

Peranan individu dalam sistem komunikasi ditentukan oleh hubungan struktur antara satu individu dengan individu lainnya dalam organisasi. hubungan ini ditentukan oleh pola hubungan interaksi individu dengan arus informasi dalam jaringan komunikasi. Untuk mengetahui jaringan komunikasi serta peranannya dapat digunakan analisis jaringan komunikasi. Menurut Suprapto (2011:82) bahwa: 
"analisis jaringan komunikasi adalah suatu metode penelitian untuk mengidentifikasi struktur komunikasi dalam suatu sistem, dimana data hubungan mengenai arus komunikasi dianalisis dengan menggunakan beberapa tipe hubunganhubungan interpersonal sebagai unit-unit analisis".

Adanya analisis jaringan komunikasi akan diketahui bentuk hubungan atau koneksi orangorang dalam organisasi serta kelompok tertentu (klik), keterbukaan satu kelompok dengan kelompok yang lainnya dan orang-orang yang memegang peranan utama dalam suatu organisasi. menurut Muhammad (1989:102-103) ada enam peranan jaringan komunikasi yaitu Opinion leader adalah pimpinan informal dalam organisasi. Mereka ini tidaklah selalu orang-orang yang mempunyai otoritas formal dalam organisasi tetapi membimbing tingkah laku anggota organisasi dan mempengaruhi keputusan mereka. Gate keepers adalah individu yang mengontrol arus informasi di antara anggota organisasi. Mereka berada di tengah suatu jaringan dan menyampaikan pesan dari satu orang kepada orang lain atau tidak memberikan informasi. Cosmopolities adalah individu yang menghubungkan organisasi dengan lingkungannya.

Mereka ini mengumpulkan informasi dari sumber-sumber yang ada dalam lingkungan dan memberikan informasi mengenai organisasi kepada orang-orang tertentu pada lingkungannya. Bridge adalah anggota kelompok atau klik dalam satu organisasi yang menghubungkan kelompok itu dengan anggota kelompok lainnya. Individu ini membantu saling memberi informasi di antara kelompok-kelompok dalam organisasi. Liaison adalah sama peranannya dengan bridge tetapi individu itu sendiri bukanlah anggota dari satu kelompok tetapi dia merupakan penghubung di antara satu kelompok dengan kelompok lainnya. Isolate adalah anggota organisasi yang mempunyai kontak minimal dengan orang lain dalam organisasi. Orang-orang ini menyembunyikan diri dalam organisasi atau diasingkan oleh teman-temannya.

Lebih lanjut Muhammad (1989:107) menjelaskan bahwa secara umum, jaringan komunikasi dibagi menjadi dua yaitu Jaringan komunikasi formal yaitu jaringan yang salurannya ditentukan oleh struktur yang telah direncanakan yang tidak dapat dipungkiri oleh organisasi. komunikasi formal ini mencakup susunan tingkah laku organisasi, pembagian departemen maupun tanggungjawab tertentu, posisi jabatan dan distribusi pekerjaan yang ditetapkan bagi anggota organisasi yang berbeda. Jaringan komunikasi informal yaitu jaringan yang salurannya tidak direncanakan dan biasanya tidaklah mengikuti struktur formal organsiasi, tetapi tinbul dari interaksi sosial yang wajar di antara anggota organisasi. Bila ditelaah, maka jaringan komunikasi formal kurang memberikan kepuasan kepada anggota organisasi terhadap kebutuhan akan informasi oleh karena itu, mereka mengembangkan kontak informal dengan desas-desus (grapevine) atau berita-berita angin yang belum tentu benar, untuk mendapatkan informasi yang menarik yang tidak mereka dapatkan dari jaringan komunikasi formal. Oleh sebab itu dalam suatu organisasi, jenis jaringan komunikasi formal dan informal selalu dipakai dalam rangka mendapatkan informasi yang menarik.

Menurut Martono (1991:2), Komunikasi yang berasal dari bahasa Latin "Communicare" yang dalam bahasa Indonesia berarti memberitahukan atau berpartisipasi, saling memberitahu berarti pula bercakap-cakap, saling berbincang-bincang saling mengemukakan buah pikiran serta merundingkan sehingga terjadi bersama persepsi. Berkomunikasi tidak terlepas dari orang lain yang diajak berkomunikasi dan yang melakukan komunikasi yang mana orang memberi komunikasi disebut Komunikator sedangkan yang menerima komunikasi disebut Komunikan. Dengan demikian komunikasi itu penting dalam kehidupan manusia karena komunikasi itu merupakan penyampaian pesan dari satu pihak kepihak lain, sehingga terjadi pengertian bersama.karena peranan komunikasi itu penting dalam kehidupan masyarakat maka dibawah ini akan dikemukakan pendapat para ahli. Menurut Martono (1991:4) mengemukakan bahwa : "Komunikasi secara sederhana dapat dilukiskan, sebagai tukar menukar informasi antara dua pelaku yakni pengirim dan pelaku penerima informasi". Selanjutnya menurut Hovland (dalam Onong, 1985:12) bahwa: "Komunikasi adalah upaya yang sistematis untuik merumuskan secara tegas asas-asas penyampaian informasi serta pembentukan pendapat dan sikap".

Dari ketiga definisi tersebut diatas dapat ditarik suatu kesimpulan bahwa komunikasi adalah proses penukaran informasi yang mengandung pengertian tertentu melalui saluran-saluran tertentu oleh seseorang kepada orang lain untuk memperoleh tanggapan.Proses penyampaian informasi pesan-pesan pembangunan haruslah menciptakan komunikasi yang positif. Lebih tegas disebut oleh Wilbur Schram (Dalam Onong, 1990 : 34). bahwa penyampaian informasi yang perlu diperhatikan hal-hal diantara lain: Pesan harus direncanakan dan disampaikan sedemikian rupa, sehingga dapat menarik perhatian komunikan. Pesan harus menggunakan lambang-lambang tertuju kepada pengalaman yang sama antara komunikator dan komunikan sehingga sama-sama mengerti. pesan harus membangkitkan kebutuhan pribadi komunikan dan menyarankan beberapa cara untuk memperoleh kebutuhan tersebut. pesan 
harus menyarankan suatu jalan untuk memperoleh kebutuhan tadi yang layak bagi situasi kelompok dimana komunikan berada pada saat ia digerakan untuk memberikan tanggapan yang dikehendaki

Penyampaian pesan-pesan melalui proses komunikasi yang sedang berlangsung akan dapat memberi pengaruh (efek) besar terhadap masyarakat. Dengan demikian aktivitas kominikator yang disampaikan kepada komunikan, diupayakan agar dapat ditanggapi dengan memberi respon atau feedback (umpan balik) sehingga terjadi kesinkronan antara dua belah pihak. Berkomunikasi tidak mudah meskipun komunikasi yang disampaikan mudah dimengerti oleh komunikan selaku penerima informasi. Dalam penyampaian berita hendaknya komunikator hendaknya menggunakan bahasa yang sederhana dan sesuai dengan kemampuan komunikan. Agar komunikasi yang dilakukan menghasilkan hasil yang baik sangat tergantung kepada kemampuan para pihak yang terlibat didalamnya baik komunikator maupun komunikan. Untuk itu berhasil tidaknya proses komunikasi yang disampaikan oleh aparat pemerintah dengan masyarakat tergantung pada keikutsertaan atau partisipasi masyarakat dalam menerima pesan-pesan pembangunan. Komunikasi merupakan suatu proses tukar menukar informasi antara dua pelaku yakni pengirim dan penerima. Manusia sebagai mahlukindividu dan mahluk social, memiliki dorongan ingin tahu, ingin maju dan berkembang, maka salah satu sarana adalah komunikasi. Karena komunikasi merupakan kebutuhan yang mutlak bagi kehidupan manusia.

Jika kita lihat lebih jauh komunikasi merupakan kegiatan manusia yang semakin otomatis karena dengan berkomunikasi manusia dapat menyampaikan pengalamannya kepada orang lain, melalui komunikasi manusia dapat merencanakan masa depan, membentuk organisasi dan lain sebagainya. Dengan komunikasi pula manusia dapat menyampaikan informasi, opini, gagasan, ide, sikap, perbuatan kepada manusia lain. Melihat uraian diatas dapat kita katakan bahwa komunikasi merupakan perwujudan dan kontak sosial yang ada didalam masyarakat serta merupakan penyampaian keinginan-keinginan serta maksud tertentu. Informasi yang disampaikan melalui komunikasi sangatlah besar pengaruhnya dalam pembangunan yang dilakukan oleh masyarakat karena dalam berkomunikasi komponen informasi yang termuat didalamnya, merupakan syarat dalam melakukan komunikasi. Menurut Widjaja (1993:11) dalam menyampaikan informasi harus memenuhi syarat berikut yakni komponen-komponen tersebut adalah a. sumber (Source) yaitu dasar yang dugunakan dalam penyampaian pesan, yang digunakan dalam rangka memperkuat pesan itu sendiri. b.Komunikator, komunikator dapat berupa individu yang sedang berbicara, menulis, sekolompok orang, organisasi seperti surat khabar, radio, televise, film dan sebagainya. c. Pesan (massage) adalah keseluruhan daripada apa yang disampaikan oleh komunikator. d.Saluran (channel) yaitu alat yang digunakan untuk menyampaikan pesan. e.Komunikasi yaitu orang yang menerima pesan. f.Effect yaitu hasil akhir dari suatu komunikasi, yaitu sikap dan tingkah laku orang, sesuai atau tidak sesuai dengan yang kita inginkan.

Berdasarkan keenam komponen diatas jelas bahwa komunikasi merupakan suatu proses penyampaian informasi yang sesuai dengan aluralur berkomunikasi. Secara sederhana informasi dalam komunikasi berfungsi untuk menginformasikan Sesuatu hal kepada orang lain. Dengan komunikasi kita dapat memperoleh informasi yang kita inginkan. Sehingga kita mudah untuk bertindak dan melakukan sesuatu dan dengan komunikasi pula kita dapat menyesuaikan diri dengan suatu kondisi yang ada pada masyarakat. Komunikasi sebagai sarana tukar menukar pengalaman, gagasan, ide dan opini maka fungsi informasi sebagai sistem sosial menurut Widjaja (1993 : 9) adalah sebagai berikut: Informasi yaitu pengumpulan, penyimpanan, pemerosesan, penyebaran berita, data, gambar, fakta dan pesan, opini dan komentar yang dibutuhkan agardapat dimengerti dan berarti secara jelas terhadap kondisi lingkungan dan orang lain. Sosialisasi (pemasyarakatan) yaitu penyediaan sumber ilmu pengetahuan yang memungkinkan orang bersikap dan bertindak sebagai anggota masyarakat yang efektif sehingga ia sadar akan fungsi sosialnya sehingga ia dapat aktif didalam masyarakat. Motivasi yaitu menjelaskan tujuan setiap masyarakat masa pendek jangka panjang, mendorong orang menentukan pilihannya dan keinginan, mendorong kegiatan individu dan kelompok berdasarkan tujuan utama yang akan dikejar. Perdebatan dan diskusi yaitu menyediakan dan saling menukar fakta yang diperlukan untuk memungkinkan persetujuan atau penyelesaian perbedaan pendapat mengenai masalah public, menyediakan bukti-bukti yang relevan yang diperlukan untuk kepentingan umum agar masyarakat lebih melibatkan diri dalam masalah yang menyangkut kepentingan bersama ditingkat nasional dan local.

Pendidikan yaitu pengalihan ilmu pengetahuan sehingga mendorong perkembangan intelektual, pembentukan watak dan pendidikan keterampilan dan kemahiran yang diperlukan pada semua bidang kehidupan. Memajukan kebudayaan yaitu penyebaran hasil kebudayaan dan seni dengan maksud mempertahankan kebudayaan. Huburan yaitu penyebaran sinyal, simbol, suara dan image 
dari drama, tari, kesenian, kesusastraan, musik, olah raga, permainan dan lain-lain. Integrasi yaitu menyediakan bagi bangsa, kelompok dan individu dan kesempatan untuk memperoleh berbagai pesan yang mereka perlukan agar mereka dapat saling kenal dan mengerti serta menghargai kondisi, pandangan dan keinginan orang lain. Berdasarkan kedelapan fungsi komunikasi dalam system social diatas dapat disimpulkan bahwa komunikasi berfungsi sebagai sarana penyampaian pikiran untuk tujuan bersama. Komunikasi yang baik adalah dapat menjalin pengertian antara pihak yang satu dengan pihak yang lain. Sehingga apa yang dikomunikasikan dapat dimengerti, dipikirkan dan akhirnya dapat dilaksanakan. Agar komunikasi yang disampaikan mudah dimengerti, maka pemberi komunikasi atau komunikator harus tahu kepada siapa komunikasi tersebut disampaikan, dalam arti tingkat pendidikan, kemampuan menerima dan lain sebagainya.

Melakukan komunikasi tentulah mempunyai tujuan tertentu untuk itu menurut pendapat Widjaja (1993:10) dikemukakan bahwa komunikasi mempunyai beberapa tujuan yaitu Supaya yang kita sampaikan dapat dimengerti. Sebagai pejabat atau komunikator kita harus menjelaskan kepada komunikan (penerima) atau bawahan dengan sebaik-baiknya dan tuntas sehingga mereka dapat mengikuti apa yang kita maksud. Memahami orang lain. Kita sebagai pejabat atau pimpinan harus mengetahui benar aspirasi masyarakat tentang apa yang diinginkan. Supaya gagasan kita dapat diterima orang lain. Kita harus mampu berusaha agar gagasan kita dapat diterima oleh orang lain dengan pendekatan yang persuasive bukan memaksakan kehendak. Mengerakan orang lain untuk melakukan sesuatu mengerakan sesuatu itu dari bermacam-macam, mungkin berupa kegiatan. Kegiatan dimaksud disini adalah kegiatan yang lebih banyak mendorong, namun yang penting kita harus ingat adalah bagaimana cara yang baik untuk melakukannya. Dengan demikian dapat disimpulkan bahwa komunikasi itu bertujuan agar orang dapat mengerti dan mengharapkan pengertian dan dukungan, serta gagasan untuk bertindak. Partisipasi merupakan keikut sertaan kita dalam sesuatu kegiatan. Komunikasi dalam suatu organisasi harus memperhatikan aspek lingkungan organisasi. menurut Sule dan Kurniawan bahwa : "lingkungan organisasi adalah kondisi tertentu yang berhubungan dan mempengaruhi gerak dan perkembangan organisasi. lingkungan organisasi terdiri dari lingkungan internal yaitu lingkungan yang terkait dengan eksistensi sebuah organisasi dan lingkungan eksternal yaitu lingkungan yang terkait kegiatan operasional organisasi ".
Menurut Muhammad (1989:214-216), ada beberapa hal dari lingkungan organisasi yang ikut memberikan kontribusi terhadap distorsi pesan dalam komunikasi, di antaranya adalah sebagai berikut Kedudukan atau Posisi dalam Organisasi. Kedudukan atau posisi dalam suatu organisasi mempengaruhi cara orang berkomunikasi. Dalam kenyataan dapat dilihat, bahwa orang yang bekerja dalam organisasi melihat pekerjaan mereka dengan cara berbeda dengan orang yang di luar organisasi. Hierarki dalam Organisasi. Susunan posisi dalam bentuk hierarki menggambarkan bahwa ada orang yang menduduki posisi yang superior dan yang lainnya bawahan. Hierarki hubungan atasan dengan bawahan ini mempengaruhi cara seorang berkomunikasi. Keterbatas Komunikasi. Keterbasan yang ditentukan oleh organisasi di mana seseorang boleh berkomunikasi dengan yang lain dan ketentuan siapa yang boleh membuat keputusan, mempengaruhi cara anggota organisasi menghendaki beberapa pembuatan keputusan secara sentralisasi. Hubungan yang Tidak Personal. Hubungan yang tidak personal dalam organisasi mempengaruhi cara orang berkomunikasi. Hubungan-hubungan yang tidak bersifat personal ini mengarahkan kepada tekanan-tekanan yang bersifat emosional.

Untuk menyembunyikan atau memungkiri ekspresi emosional kepada orang lain orang mengembangkan cara-cara menyimpan ekspresi emosional tersebut. Sistem Aturan dan Kebijaksanaan. Sistem aturan, kebijaksanaan dan aturan-aturan yang berkenaan dengan pemikiran dan perbuatan, mempengaruhi cara-cara orang berkomunikasi. Spesialisasi Tugas. Spesialisai tugas mempersempit persepsi seseorang dan mempengaruhi cara orang berkomunikasi. Ketidakpedulian Pimpinan. Sikap tidak peduli pimpinan organisasi juga merupakan penghalang dalam proses komunikasi. Ada empat hal yang memberikan sumbanganterhadap sikap tidak peduli ini yaitu Pimpinan sering gagal mengirim pesanyang dibutuhkan karyawan karenamereka mengira bahwa orang telah mengetahui, mereka malas, menangguhkan dan cenderung menahan informasi. Kebanyakan organisasi pada dasarnya tidak menginginkan komunikasi dua arah. Kondisi yang menghalangi komunikasi yang efektif dan dihubungkandengan tidak ambil pusing yang mendalam. Keragu-raguan dan daya tahanperhatian yang sebentar merupakanhambatan bagi komunikasi yang efektif. Prestise. Prestise datang dari bermacam-macam bentuk seperti besarnya kantor atau ruang kerja, kemewahan perabotan kantor dan sekretaris pribadi. Jaringan komunikasi. Hambatan yang lain juga dapat disebabkan oleh karena banyaknya tingkatan atau mata rantai yang harus dilalui oleh suatu pesan dalam komunikasi. Pesan yang dikirimkan secara 
seri atau berantai banyak cenderung diubah oleh si penerima sebelum dilanjutkan pengirimannya.

Perubahan lingkungan organisasi baik lingkungan internal maupun eksternal organisasi tidak lepas dari aspek komunikasi. Perubahan secara eksternal seperti perkembangan teknologi alat komunikasi akan berpengaruh terhadap proses penyampaian pesan. Kalau dulu orang mau berbicara harus bertemu dan berhadap-hadapan, namun setelah adanya alat komunikasi berupa telepon maupun handphone maka pembicaraan bisa dilakukan dari jarak jauh sehingga pesan bisa disampaikan lewat jarak jauh. Menurut Sulistiyani dan Rosidah (2009:34), bahwa komunikasi Informal adalah: "komunikasi yang ada di luar struktur, biaasanya melalui saluran-saluran non formal yang munculnya bersifat insidental, menurut kebutuhan atau hubungan interpersonal yang baik, atau atas dasar kesamaan kepentingan, hobi dan lain-lain". Jalur/saluran komunikasi diperlihatkan oleh adanya jalur-jalur komunikasi formal yang dirancang dalam organisasi. Saluran hubungan yang bersifat sentralistik diwakili oleh bentuk komunikasi komando, yang menyalurkan komunikasi dari atas ke bawah (down-ward communication). Biasanya bentuk saluran komunikasi semacam itu diimbangi dengan saluran ke atas atau dikanal dengan upwardcommunication. Bentuk lain yang sering tampak dalam organisasi publik adalah komunikasi diagonal yang memberikan ruang terjadinya komunikasi antar sesama.

Bentuk terapan yang sering ditemui dalam organisasi publik pada umumnya merupakan bentuk komunikasi yang sentralistik. Pada saluran hubungan yang sentralistik biasanya didominasi oleh pimpinan sebagai sumber berita. Pimpinan dalam hal ini akan bertindak sebagai orang pertama yang memberi informasi, sedangkan anak buah tinggal menjadi pelaksana. Kondisi semacam ini menempatkan pimpinan sebagai satu-satunya orang yang menguasai informasi. Komunikasi yang tersentral jauh lebih miskin variasi atau corak informasi. Hanya terdapat dua jenis komunikasi yang cukup menonjol dalam hal ini, yaitu perintah dan pertanggungjawaban. Sedangkan pada komunikasi yang lebih terbuka, sangat memungkinkan terbentuknya variasi informasi, baik yang berasal dari inisiatif atasan maupun bawahan. Komunikasi yang berupa konsultasi, pembimbingan, saran nasihat, kritik dan lain-lain merupakan variasi yang dapat ditampung pada pola komunikasi yang fleksibel.

Menurut Mulyana (2005:85), secara umum ragam tingkatan komunikasi adalah sebagai berikut: Komunikasi intrapribadi (intrapersonal communication) yaitu komunikasi yang terjadi dalam diri seseorang yang berupa proses pengolahan informasi melalui panca indra dan sistem saraf manusia. Komunikasi antarpribadi (interpersonal communication) yaitu kegiatan komunikasi yang dilakukan seseorang dengan orang lain dengan corak komunikasinya lebih bersifat pribadi dan sampai pada tataran prediksi hasil komunikasinya pada tingkatan psikologis yang memandang pribadi sebagai unik. Dalam komunikasi ini jumlah prilaku yang terlibat pada dasarnya bisa lebih dari dua orang selama pesan atau informasi yang disampaikan bersifat pribadi. Komunikasi kelompok (group communication) yaitu komunikasi yang berlangsung diantara anggota suatu kelompok. Komunikasi kelompok sebagai interaksi tatap muka dari tiga atau lebih individu guna memperoleh maksud atau tujuan yang dikehendaki seperti berbagi informasi, pemeliharaan diri atau pemecahan masalah sehingga semua anggota dapat menumbuhkan karakteristik pribadi anggota lainnya dengan akurat. Komunikasi organisasi (organization communication) yaitu pengiriman dan penerimaan berbagai pesan organisasi didalam kelompok formal maupun informal dari suatu organisasi. Komunikasi massa (mass communication). Komunikasi massa dapat didefinisikan sebagai suatu jenis komunikasi yang ditujukan kepada sejumlah audien yang tersebar, heterogen dan anonym melalui media massa cetak atau elektronik sehingga pesan yang sama dapat diterima secara serentak dan sesaat.

Selain itu, Terry (1972:214) menjelaskan bahwa secara garis besar terdapat 5 (lima) bentuk komunikasi dalam manajemen yaitu Komunikasi formal, biasanya adalah bentuk komunikasi dalam jalur organisasi formal, memiliki wewenang dan tanggung jawab yaitu melalui intruksi-intruksi bentuk lisan dan tertulis sesuai dengan prosedur secara fungsional yang berlaku. Juga memiliki arus komunikasi atasan kebawah atau sebaliknya. Komunikasi non-formal, yaitu bentuk komunikasi yang secara fungsi fungsional berada diluar komunikasi formal. Komunikasi ini dapat terjadi secara tiba-tiba atau sepontanitas dalam kondisi yang tidak diharapkan terjadi komunikasi formal seperti hubungan antar pribadi untuk menjelaskan atau memberikan saran yang berkaitan dengan tugas dan kewajiban. Biasanya komunikasi non formal cukup efektif dilakukan pada perusahaan bersifat padat karya dengan jumlah pekerja cukup banyak, serta tidak terlalu teknis, cara bekerja permanen dan terus menerus atau kontinu. Komunikasi informal. Bentuk komunikasi ini mungkin lebih dekat kepada komunikasi non-formal, berkaitan dengan aspek-aspek kejiwaan, bersifat lebih sensitif dan sentimental karena didominasi oleh kontak hubungan antara manusia. Komunikasi informal tersebut banyak dipergunakan oleh devisi personalia dalam upaya menggali atau mengetahui lebih mendalam mengenai kaitan aspek psikologis karyawan setelah sebelumnya menunjukkan 
prestasi yang memuaskan dengan kehidupan seharihari di luar pekerjaannya.

Komunikasi teknis, hubungan komunikasi di sini lebih bersifat dan hanya dapat dipamahi atau dimengerti oleh para ahli atau pekerja khusus yang berkaitan dengan pekerjaan tertentu. Misalnya komunikasi bidang pekerjaan teknik mesin industri, arsitek, rancang bangun/kontruksi dan program komputerisasi, internet serta elektronik-mail ( $E$ mail) dan lain sebagainya. Komunikasi prosedural, bentuk komunikasi ini lebih dekat kepada komunikasi formal. Contohnya adalah pedoman teknis pekerjaan (petunjuk manual, peraturan perusahaan atau kebijaksanaan pimpinan, intruksi tertulis, memo, laporan berkala bulanan/tahunan, tata cara proses dan penyelesaian suatu pekerjaan. Termasuk pula dalam bentuk komunikasi ini adalah hubungan pekerjaan antara pimpinan dan bawahan yang ditetapkan dalam bentuk peraturan tertulis dan rinci mengenai suatu deskripsi jabatan (penjelasan) dan spesifikasi (persyaratan), baik yang berkenaan dengan fungsi, wewenang, maupun tanggung jawab masing-masing personil/karyawan.

Demikian pula pendapat Cangara (1998:3034) bahwa bentuk atau tipe komunikasi dapat dibedakan menjadi 4 (empat) yaitu Komunikasi dengan diri sendiri (intrapersonal communication). Komunikasi dengan diri sendiri adalah yang terjadi di dalam diri individu, atau dengan kata lain proses berkomunikasi dengan diri sendiri. Komunikasi antar pribadi (interpersonal communication).

Komunikasi antar pribadi adalah proses komunikasi yang berlangsung antara dua orang atau lebih secara tatap muka. Komunikasi publik (public communication). Komunikasi publik menunjukkan suatu proses komunikasi dimana pesan-pesan disampaikan oleh pembicara dalam situasi tatap muka di depan khalayak yang lebih besar. Komunikasi massa (mass communication). Komunikasi massa dapat didefinisikan sebagai proses komunikasi yang berlangsung dimana pesannya dikirim dari sumber yang melembaga kepada khayalak yang bersifat massal melalui alatalat yang bersifat mekanis seperti radio, televisi, surat kabar dan film.

Menurut Effendy (2000:17) bahwa bentukbentuk komunikasi dapat dijabarkan sebagai berikut Komunikasi vertical. Komunikasi vertikal adalah komunikasi dari atas ke bawah dan dari bawah ke atas atau komunikasi dari pimpinan ke bawahan dan dari bawahan ke pimpinan secara timbal balik. Komunikasi horizontal. Komunikasi horisontal adalah komunikasi secara mendatar, misalnya komunikasi antara karyawan dengan karyawan dan komunikasi ini sering kali berlangsung tidak formal yang berlainan dengan komunikasi vertikal yang terjadi secara formal. Komunikasi diagonal.
Komunikasi diagonal yang sering juga dinamakan komunikasi silang yaitu seseorang dengan orang lain yang satu dengan yang lainnya berbeda dalam kedudukan dan bagian. Kee khasan bentuk komunikasi yang menempatkan manusia sebagai unsur penting dalam organisasi haruslah diwarnai oleh sikap dan pola komunikasi yang bijak. Sikap dalam hal ini lebih mengekspresikan bagaimana manusia diletakkan pada posisi yang terhormat dan dipandang berharga. Kondisi semacam ini apakah mewarnai dalam sistem komunikasi antara pimpinan dengan bawahan dan antar sesamanya. Pengamatan dapat dilakukan sejauh mana pimpinan memperlakukan bawahan dalam komunikasi baik formal maupun non formal.

Dalam melaksanakan tugas dan tanggungjawabnya, pimpinan dan bawahan perlu adanya komunikasi dua arah berdasarkan hubungan manusia yang baik (good human relations). Menurut Abdurrachman (2001:35), bahwa:

Komunikasi yang dilaksanakan oleh pimpinan terhadap bawahan (downward communication) tidak akan mengalami banyak kesulitan, tetapi sebaliknya, komunikasi yang berjalan dari bawah ke atas (upward communication) besar kemungkinan akan mengalami hambatanhambatan. Ini disebabkan karena faktor-faktor psikologis, sosiologis, pendidikan dan lain-lain. Demikian pula dalam komunikasi antar kolega (komunikasi yang berjalan horisontal) dapat timbul kesulitan-kesulitan, karena misalnya: tiap anggota merasa tugasnya lebih penting daripada anggota lainnya, atau tiap kelompok profesional merasa profesinya lebih tinggi daripada profesi atau bidang lainnya. Oleh sebab itu pimpinan untuk menyelenggarakan komunikasi yang sifatnya persuasif dan informatif. Menurut Abdurrachman (2001:35) bahwa komunikasi yang informatif dan persuasif dapat dilaksanakan dengan Tertulis, yaitu menggunakan surat-surat, papers, buletin dan brosur. Lisan, yaitu mengadakan brieving, rapatrapat, diskusi dan ceramah. Konseling, yaitu menyediakan beberapa anggota staf yang telah mendapatkan latihan atau pendidikan untuk memberikan nasehat-nasehat kepada para pegawai, turut memecahkan masalah-masalah pribadi mereka atau mendiskusikannya bersama-sama.

Menurut Purwanto (2006:190)cbahwa dalam proses komunikasi terdiri dari 5 (lima) komponen yaitu Komunikator. Untuk melaksanakan komunikasi efektif terdapat dua faktor pendukung dari komunikator, yaitu kredibilitas komunikator dan daya tarik komunikator, kredibilitas seseorang akan menentukan tersampaikannya pesan dalam komunikasi, misalnya seseorang atasan yang baik akan dengan mudah menyampaikan pesan yang berisi tentang perintah, untuk mengerjakan pekerjaan yang berkenaan dengan lembaga atau perusahaan dimana mereka bekerja. Demikian juga 
orang yang memiliki charisma akan dengan mudah menyampaikan pesan dan akan mudah mempengaruhi orang-orang yang diajak berkomunikasi dan yang ada disekelilingnya. Pesan. Pesan merupakan materi atau bentuk fisik dari idea tau informasi yang disampaikan kepada komunikan. Dari pesan yang dikirimkan ini seorang komunikator menghendaki bagaimana reaksi dari komunikan dan apa umpan baliknya.

Seperti sudah dikatakan diatas bahwa kemasan pesan harus disesuaikan dengan situasi dan kondisi yang ada. Saluran. Yang dimaksud dengan saluran adalah sarana tempat berlalunya pesan dari pengirim dengan si Penerima. Saluran tersebut adalah pendengaran, untuk berlalunya pesan yang berupa suara, pengelihatan untuk pesan yang berupa sinar, penciuman untuk berlalunya pesan yang berupa bau-bauan, rabaan untuk pesan yang berupa rangsangan rabaan dan sebagainya. Komunikan. Komunikan adalah yang menganalisis dan menginterprestasikan isi pesan yang diterimanya. Komunikan sebagai makhluk sosial, maka komunikan akan bersosialisasi dengan lingkungannya, dengan demikian ia akan menerima pengaruh dari lingkungan dan sekaligus memberi pengaruh pada lingkungannya. Dengan demikian komunikator harus memperhatikan faktor ini,jangan sampai komunikan dianggap sebagai makhluk yang tidak bersosialisasi, sehingga ia tidak terpengaruh dan mempengaruhi manusia lainnya. Efek (umpan balik). Dampak atau akibat dari pesan yang diperkirakan akan terjadi dan menimbulkan efek atau pengaruh tertentu (opini, persepsi dan citra) dari komunikan. Unsur-unsur komunikasi tersebut saling berkaitan karena sebagai komunikator dapat menyampaikan berita (dapat berupa perintah, saran, usul dan lain sebagainya) melalui media atau sarana kepada komunikan harus jelas sehingga terjadi umpan balik atau respon dari komunikan. Komunikasi dikatakan berhasil bila tafsiran komunikasi (penerima) tersebut dapat menerima maksud dari si komunikator (pengirim). Bila tidak sesuai maka disebut salah komunikasi.

\section{METODE}

Penelitian ini jenisnya penelitian deskriptif, Adapun yang menjadi subjek penelitian adalah Kepala Dinas Pekerjaan Umum, Kepala Bidang Pada Dinas Pekerjaan Umum, Kepala Subbagian pada Dinas Pekerjaan Umum, Beberapa Pegawai Pada Dinas Pekerjaan Umum. D alam pengumpulan data, penelitian ini digunakan tehnik Pengamatan/Observasi, Wawancara atau interview dan Studi Dokumentasi dengan alat pengumpulan data sebagai Pedoman Wawancara, Panduan Observasi, Untuk memperoleh Dukomentasi digunakan alat bantu fotocopi. Pada teknik analisis data yang digunakan adalah teknik analisis kualitatif, yakni data yang terkumpul baik data primer maupun data sekunder diklasifikasikan sesuai dengan jenis data dan kemudian dideskripsikan ataupun dengan menggunakan ungkapan-ungkapan kalimat sebagai interprestasi atau penafsiran dari indikator penelitian yang diajukan untuk selanjutnya dibuat suatu kesimpulan.

\section{HASIL PENELITIAN DAN PEMBAHASAN}

Berdasarkan hasil penelitian bahwa Komunikasi formal adalah suatu proses komunikasi yang bersifat resmi dan biasanya dilakukan Dinas di dalam lembaga formal melalui garis perintah atau sifatnya instruktif, berdasarkan struktur organisasi oleh pelaku yang berkomunikasi sebagai petugas organisasi dengan status masing-masing yang tujuannya menyampaikan pesan yang terkait dengan kepentingan dinas. Suatu komunikasi juga dapat dikatakan formal ketika komunikasi antara dua orang atau lebih yang ada pada suatu organisasi dilakukan berdasarkan prinsip- prinsip dan struktur organisasi. Selanjutnya berdasarkan hasil penelitian, Komunikasi dapat menghubungkan antara bagian yang berbeda atau disebut rantai pertukaran informasi. Hal ini mengandung unsur-unsur yakni Sebagai kegiatan seseorang untuk megertidan Sebagai sarana pengendalian informasi, Sebagai sistem bagi terjalinnya komunikasi diantara individuindividu.

Berdasarkan hasil penelitian terungkap bahwa komunikasi yang dilakukan selama ini yakni komunikasi dari atas ke bawah, dari bawah ke atas, horisontal dan diagonal. Dari hasil beberapa wawancara bahwa Komunikasi dari atas ke bawah (downward communication). merupakan aliran komunikasi dari tingkat atas ke tingkat bawah melalui hirarki organisasi. Bentuk dari aliran komunikasi ini misalnya prosedur organisasi, instruksi tentang bagaimana melakukan tugas, umpan balik terhadap bawahan dan sebagainya. Komunikasi dari bawah ke atas dirancang untuk menyediakan umpan balik tentang seberapa baik organisasi telah berfungsi. Bawahan diharapkan memberikan informasi tentang prestasinya dan praktek serta kebijakan organisasi. Komunikasi horisontal merupakan aliran komunikasi kepada orang-orang yang memiliki hirarki yang sama dalam suatu organisasi. Serta komunikasi diagonal merupakan aliran komunikasi dari orang-orang uang memiliki hirarki yang berbeda dan tidak memiliki hubungan wewenang secara langsung.

Berdasarkan hasil penelitian komunikasi yang mereka lakukan merupakan Komunikasi antar pribadi, Komunikasi Kelompok dan Komunikasi Massa, lebih lanjut dari penjelasan beberapa Kepala diperoleh informasi bahwa komunikasi antar pribadi yakni Komunikasi yang 
penerapannya antara pribadi/individu dalam usaha menyampaikan informasi yang dimaksudkan untuk mencapai kesamaan pengertian, sehingga dengan demikian dapat tercapai keinginan bersama.Komunikasi kelompok yakni Pada prinsipnya dalam melakukan suatu komunikasi yang ditekankan adalah faktor kelompok, sehingga komunikasi menjadi lebih luas. Dalam usaha menyampaikan informasi, komunikasi dalam kelompok tidak seperti komunikasi antar pribadi, Dan Komunikasi massa yakni dilakukan dengan melalui alat, yaitu media massa yang meliputi cetak dan elektronik.

Berdasarkan hasil penelitian diruang kerjanya diproleh informasi bahwa yang dijalankan selama ini cukup baik, baik komunikasi Vertikal, komunikasi horisontal maupun komunikasi diagonal. Berdasarkan data dan hasil observasi bahwa komunikasi sebagai bentuk komunikasi vertikal telah dilakukan dapat dilihat padda tabel berikut:

Tabel. 1. Keadaan Bentuk serta Fungsi Komunikasi Vertikal pada Dinas Pekerjaan Umum Kabupaten Melawi Tahun 2012

\begin{tabular}{|c|l|c|}
\hline \multirow{2}{*}{ No } & \multicolumn{1}{|c|}{ Uraian Fungsi Komunikasi } & Keterangan \\
\hline \multirow{4}{*}{1} & Melaksanakan kebijaksanaan; & \\
\cline { 2 - 3 } & a. Prosedur kerja & ada \\
\cline { 2 - 3 } & b. Peraturan & ada \\
\cline { 2 - 3 } & c. Instruksi & ada \\
\cline { 2 - 3 } & d. Mengenai pelaksanaan kerja bawahan & ada \\
\hline \multirow{2}{*}{2} & Menyampaikan pengarahan doktrinasi; & ada \\
\cline { 2 - 3 } & a. Evaluasi & ada \\
\cline { 2 - 3 } 3 & b. Teguran & Memberikan informasi mengenai tujuan organisasi \\
\hline \multirow{2}{*}{3} & a. Kebijaksanaan-kebijaksaan organisasi & ada \\
\hline & b. Insentif & ada \\
\hline
\end{tabular}

Sumber: Hasil Observasi, 2013.

Berdasarkan tabel diatas di ketahui bahwa Bentuk komunikasi Vertikal ini merupakan bentuk komunikasi yang terjadi dari atas ke bawah dan sebaliknya. Artinya komunikasi yang disampaikan pimpinan kepada bawahan, dan dari bawahan kepada pimpinan secara timbal balik. Komunikasi tersebut yakni; 1) Melaksanakan kebijaksanaan, prosedur kerja, peraturan, instruksi, mengenai pelaksanaan kerja bawahan; 2) Menyampaikan pengarahan doktrinasi, evaluasi, teguran; 3) Memberikan informasi mengenai tujuan organisasi, kebijaksanaan-kebijaksaan organisasi, insentif. Dari tabel diatas juga dapat di pahami bahwa akomunikasi vertikal juga digunakan untuk: a) Memberikan pengertian mengenai laporan prestasi kerja, saran, usulan, opini, permohonan bantuan, dan keluhan; b) Memperoleh informasi dari bawahan mengenai kegiatan dan pelaksanaan pekerjaan bawahan dari tingkat yang lebih rendah sehingga Bawahan tentulah berharap agar ide, saran, pendapat, tanggapan maupun kritikannya dapat diterima dengan lapang dada, dan hati terbuka oleh pimpinan.
Selanjutnya hasil penelitian, kebijaksanaan-kebijaksaan organisasi Bentuk komunikasi secara mendatar, diantara sesama pegawai pada kebijaksanaan-kebijaksaan organisas juga sering berlangsung Komunikasi ini disebut komunikasi horizontal. Fungsi komunikasi horizontal/ke samping digunakan oleh dua pihak yang mempunyai level yang sama. Dari hasil pengamatan (Observasi) peneliti Komunikasi ini berlangsung dengan cara tatap muka, melalui media elektronik seperti telepon, atau melalui pesan tertulis. Hasil penelitian bahwa ada Komunikasi diagonal yakni Bentuk komunikasi ini sering disebut juga komunikasi silang. Berlangsung dari seseorang kepada orang lain dalam posisi yang berbeda. Dalam arti pihak yang satu tidak berada pada jalur struktur yang lain. Fungsi komunikasi diagonal digunakan oleh dua pihak yang mempunyai level berbeda tetapi tidak mempunyai wewenang langsung kepada pihak lain.

Dari beberapa hasil penelitian dapat dianalisis bahwa landasan konsep-konsep 
komunikasi dan organisasi sebagaimana yang telah diuraikan, maka kita dapat memberi batasan tentang komunikasi dalam organisasi secara sederhana, yaitu komunikasi antar manusia (human communication) yang terjadi dalam kontek organisasi. Atau dengan meminjam definisi dari Goldhaber, komunikasi organisasi diberi batasan sebagai arus pesan dalam suatu jaringan yang sifat hubungannya saling bergabung satu sama lain (the flow of messages within a network of interdependent relationships). Sebagaimana telah uraikan bahwa arus komunikasi dalam organisasi meliputi komunikasi vertikal dan komunikasi horisontal. Masing-masing arus komunikasi tersebut mempunyai perbedaan fungsi yang sangat tegas. Ronald Adler dan George Rodman dalam buku Understanding Human Communication, mencoba menguraikan masing-masing, fungsi dari kedua arus komunikasi dalam organisasi tersebut sebagai berikut: 1. Downward communication, yaitu komunikasi yang berlangsung ketika orang-orang yang berada pada tataran manajemen mengirimkan pesan kepada bawahannya. Fungsi arus komunikasi dari atas ke bawah ini adalah: a) Pemberian atau penyimpanan instruksi kerja (job instruction); b) Penjelasan dari pimpinan tentang mengapa suatu tugas perlu untuk dilaksanakan (job retionnale); c) Penyampaian informasi mengenai peraturanperaturan yang berlaku (procedures and practices); d) Pemberian motivasi kepada pegawai untuk bekerja lebih baik. 2. Upward communication, yaitu komunikasi yang terjadi ketika bawahan (subordinate) mengirim pesan kepada atasannya. Fungsi arus komunikasi dari bawah ke atas ini adalah: a). Penyampaian informai tentang pekerjaan pekerjaan ataupun tugas yang sudah dilaksanakan; b) Penyampaian informasi tentang persoalan-persoalan pekerjaan ataupun tugas yang tidak dapat diselesaikan oleh bawahan; c) Penyampaian saran-saran perbaikan dari bawahan; d) Penyampaian keluhan dari bawahan tentang dirinya sendiri maupun pekerjaannya. 3. Horizontal communication, yaitu tindak komunikasi ini berlangsung di antara para karyawan ataupun bagian yang memiliki kedudukan yang setara. Fungsi arus komunikasi horisontal ini adalah: a) Memperbaiki koordinasi tugas; b) Upaya pemecahan masalah; c) Saling berbagi informasi; d) Upaya pemecahan konflik; e) Membina hubungan melalui kegiatan bersama.

Berdasarkan hasil penelitian, komunikasi antara orang yang ada dalam suatu organisasi, akan tetapi tidak direncanakan atau tidak ditentukan dalam struktur organisasi. Disampaikan juga bahwa Fungsi komunikasi informal adalah untuk memelihara hubungan sosial persahabatan kelompok informal, penyebaran informasi yang bersifat pribadi dan privat seperti isu, gossip, atau rumor. Berdasarkan hasil penelitian bahwa komunikasi informal adalah komunikasi yang dilakukan berdasarkan informasi yang masih belum jelas dan tidak akurat, carilah sumber informasi yang dapat dipercaya, selalu gunakan akal sehat dan bertindak berdasarkan pikiran yang positif. Informasi dalam komunikasi informal biasanya timbul melalui rantai kerumunan di mana seseorang menerima informasi dan diteruskan kepada seseorang atau lebih dan seterusnya sehingga informasi tersebut tersebar ke berbagai kalangan. Implikasinya adalah kebenaran informasi tersebut menjadi tidak jelas atau kabur. Meski demikian komunikasi informal akan untuk memenuhi kebutuhan sosial, mempengaruhi orang lain, dan mengatasi kelambatan komunikasi formal yang biasanya cenderung kaku dan harus melalui berbagai jalur terlebih dahulu.

Dari berapa hasil penelitian dapat menganalisis bahwa Komunikasi informal adalah proses komunikasi yang berada di antara yang formal atau resmi dengan yang tidak resmi atau informal. Komunikasi jenis ini biasanya berupa komunikasi yang berhubungan dengan hubungan pribadi. Komunikasi informal adalah komunikasi yang terjadi diluar dan tidak tergantung pada herarki wewenang. Komunikasi informal ini timbul karena adanya berbagai maksud, yaitu Pemuasan kebutuhan manusiawi, Perlawanan terhadap pengaruh yang monoton dan membosankan, Keinginan untuk mempengaruhi perilaku orang lain, Sumber informasi hubungan pekerjaan.

Jenis lain dari komunikasi informasi adalah adalah dasas-desus yang secara resmi tidak setuju. Desas-desus ini juga mempunyai peranan fungsional sebagai alat komunikasi tambahan bagi organisasi. Menurut peneliti bahwa kominikasi Dalam suatu organisasi baik yang berorientasi komersial maupun sosial, tindak komunikasi dalam organisasi atau lembaga tersebut akan melibatkan empat fungsi yang sesuai dengan teori, yaitu 1 . Fungsi informatif

Organisasi dapat dipandang sebagai suatu sistem pemrosesan informasi (information-processing system). Maksudnya, seluruh anggota dalam suatu organisasi berharap dapat memperoleh informasi yang lebih banyak, lebih baik dan tepat waktu. Informasi yang didapat memungkinkan setiap anggota organisasi dapat melaksanakan pekerjaannya secara lebih pasti informasi pada dasarnya dibutuhkan oleh semua orang yang mempunyai perbedaan kedudukan dalam suatu organisasi. Orang-orang dalam tataran manajemen membutuhkan informasi untuk membuat suatu kebijakan organisasi ataupun guna mengatasi konflik yang terjadi di dalam organisasi. Sedangkan karyawan (bawahan) membutuhkan informasi tentang jaminan keamanan, jaminan sosial dan 
kesehatan, izin cuti dan sebagainya. 2. Fungsi Regulatif. Fungsi regulatif ini berkaitan dengan peraturan-peraturan yang berlaku dalam suatu organisasi. Pada semua lembaga atau organisasi, ada dua hal yang berpengaruh terhadap fungsi regulatif ini, yaitu: atasan atau orang-orang yang berada dalam tataran manajemen yaitu mereka yang memiliki kewenangan untuk mengendalikan semua informasi yang disampaikan. Disamping itu mereka juga mempunyai kewenangan untuk memberikan instruksi atau perintah, sehingga dalam struktur organisasi kemungkinan mereka ditempatkan pada lapis atas (position of authority) supaya perintah-perintahnya dilaksanakan sebagaimana semestinya. Namun demikian, sikap bawahan untuk menjalankan perintah banyak bergantung pada: keabsahan pimpinan dalam penyampaikan perintah kekuatan pimpinan dalam memberi sanksi kepercayaan bawahan terhadap atasan sebagai seorang pemimpin sekaligus sebagai pribadi tingkat kredibilitas pesan yang diterima bawahan. berkaitan dengan pesan atau message. Pesan-pesan regulatif pada dasarnya berorientasi pada kerja. Artinya, bawahan membutuhkan kepastian peraturan-peraturan tentang pekerjaan yang boleh dan tidak boleh untuk dilaksanakan.3. Fungsi Persuasif. Dalam mengatur suatu organisasi, kekuasaan dan kewenangan tidak akan selalu membawa hasil sesuai dengan yang diharapkan. Adanya kenyataan ini, maka banyak pimpinan yang lebih suka untuk mempersuasi bawahannya daripada memberi perintah. Sebab pekerjaan yang dilakukan secara sukarela oleh karyawan akan menghasilkan kepedulian yang lebih besar dibanding kalau pimpinan sering memperlihatkan kekuasaan dan kewenangannya. 4. Fungsi Integratif. Setiap organisasi berusaha menyediakan saluran yang memungkinkan karyawan dapat dilaksanakan tugas dan pekerjaan dengan baik. Ada dua saluran komunikasi formal seperti penerbitan khusus dalam organisasi tersebut (newsletter, buletin) dan laporan kemajuan oraganisasi; juga saluran komunikasi informal seperti perbincangan antarpribadi selama masa istirahat kerja, pertandingan olahraga ataupun kegiatan darmawisata. Pelaksanaan aktivitas ini akan menumbuhkan keinginan untuk berpartisipasi yang lebih besar dalam diri karyawan terhadap organisasi.

\section{KESIMPULAN DAN SARAN}

Berdasarkan uraian data serta hasil penelitian mengenai masalah komunikasi Antar Pegawai , dengan aspek Komunikasi formal Antar Pegawai telah dilakukan dengan bebagai bentuk baik vertikal, harisontal maupun diagonal dan telah difungsikan sebagai sarana penyampaian informasi yang berhubungan kebijak, pembagian tugas, evaluasi dan juga merupakan sebagai fungsi pelaporan dan opini, sedangkan aspek Komunikasi Informal Antar Pegawai juga dilakukan walaupun sebatas isu, gosip yang sumbernya belum dapat dipertanggungjawabkan tapi pegawai memilah informasi dalam komunikasi tersebut dan komunikasi informal in juga sebagai media untuk memelihara hubungan sosial persahabatan kelompok informal. maka dengan ini peneliti menyarankan agar komunikasi yang digunakan dapat bermanfaat bagi pegawai dalam membangun kometmen dan sinergilitas serta loyalitas terhadap tugas pokok dan fungsi dari penyelenggara aparatur pemerintah.

\section{DAFTAR PUSTAKA}

Abdurrachman, O. 2011. Dasar-Dasar Public Relations. Bandung: PT. Citra Aditya Bakti.

Argiris C. 1994. Good Communication That Block Learning. HBR. July-Agustus.

Blake, Reed H., and Haroldsen, Edwin O. 2003. Taksonomi Konsep Komunikasi. Cetakan Ke-I. Terj. Hasan Bahanan. Surabaya: Papyrus.

Burgon, L. dan Huffner, S. 2002. Communication for Publik Relations. New York: McMillan Co. Publisher.

Cangara, H. 1998. Pengantar Ilmu Komunikasi. Jakarta: PT. Raja Grafindo Persada.

Chase, H. 2001. Operation Management for Competitive Advantage. New York: McMillan Co. Publisher.

Creven, David W. 1998. Pemasaran Strategis. Edisi ke-4. Jilid I. Jakarta: Erlangga.

Daft, Richard L. 2003. Manajemen. Edisi ke-5. Cetakan ketujuh. Jakarta: Erlangga.

Effendy, Onong Uchjana. 2000. Dinamika Komunikasi. Jakarta: PT. Raja Grafindo Persada.

2004. Komunikasi $\bar{A} \bar{d}$ ministrasi. Bandung: PT. Remaja Rosdakarya.

Gie, The Liang. 2002. Administrasi Perkantoran Modern. Edisi keempat. Cetakan kedelapan. Yogyakarta: Liberty.

Hewitt, D. 1981. Administration of Communication. New York: Mc Grawhill Press.

Kotler, P. 1985. Manajemen Pemasaran. Jakarta: PT. Gramedia. 
Kusnadi, H. M. 2005. Pengantar Manajemen (Konsepsual \& Perilaku). Malang : Unbraw.

Manullang, M. 2005. Dasar-Dasar Manajemen. Yogyakarta: Gajah Mada University Press.

Marbun, BN. 2005. Kamus Manajemen. Jakarta: Bumi Aksara.

Moenir, H. A. S. 2002. Manajemen Pelayanan Umum di Indonesia. Cetakan Keenam. Jakarta: Bumi Aksara.

Muhammad, A. 1989. Komunikasi Organisasi. Jakarta: Bumi Aksara.

Mulyana, Deddy. 2005. Ilmu Komunikasi: Suatu Pengantar. Bandung : Remaja Rosdakarya.

Nitisemito, Alex S. 1996. Manajemen Personalia (manajemen Sumber daya manusia). Jakarta : Ghalia Cipta.

Pawito, dan C Sardjono. 1994. Teori-Teori Komunikasi. Buku Pegangan Kuliah Fisipol Komunikasi Massa S1 semester IV. Surakarta: Universitas Sebelas Maret.

Purwanto, Djoko. 2006. Komunikasi Bisnis FEU Sebelas Maret. Surakarta: Erlangga.

Riswandi. 2006. Definisi Komunikasi dan Tingkatan Proses Komunikasi. Word Press.com 17 oktober 2006. 10 juni 2010. (Http: //meiliemma. wordpress.com/2006/10/17/ definisikomunikasi- dan - tingkatan- proses komunikasi).
Rubben, S.P. 1992. Prinsip-Prinsip Prilaku Organisasi. Edisi Kelima. Cetakan ketujuh. Jakarta : Erlangga.

Schramm. L.H. 1964. Efectivity Communication for Public Relation. New York: Prentichall.

Sofyandi, Herman dan Garniwa, Iwa. 2007. Perilaku organisasi. edisi pertama. Cetakan pertama. Yogyakarta: Graha Ilmu.

Sugiarto. 2002. Psikologi Pelayanan Dalam Industri Jasa. Jakarta: PT. Gramedia.

Sulistiyani, Ambar Teguh dan Rosidah.2009. Manajemen Sumber Daya Manusia: Konsep,Teori dan Pengembangan dalam Konteks Organisasi Publik. Edisi Kedua. Cetakan Pertama. Yogyakarta: Graham Ilmu.

Suprapto,Tommy. 2006. Pengantar Teori Komunikasi. Cdetakan Kesatu. Yogyakarta: Media Pressindo.

Swashta, Basu. 1995. Pengantar Bisnis Modern (Pengantar Ekonomi Perusahaan Modern). Yogyakarta: Liberty.

Terry, G.R. 1972. Principles of Management, 6th edition. Georgetown: Richard D Irving Inc.

Tunggal, A.W. 1996. Reformasi Pelayanan Publik Teori, Kebijakan dan Implementasi. Jakarta: Bina Aksara.

Wexley dan Yulk. 1996. Perilaku Organisasi dan Psikologi Personalia. Jakarta: Rineka Cipta.

Wiryanto. 2005. Teori Komunikasi Massa. Jakarta: PT. Grasindo. 